\title{
Prediction of Seedling Establishment in Field by Using Various Seed Vigour Parameters in Wheat (Triticum spp.)
}

\author{
Sushma Sharma ${ }^{1 *}$, R.C. Punia ${ }^{1}$, Vikram Singh ${ }^{2}$, V.S. Mor ${ }^{1}$ and Hemender ${ }^{1}$ \\ ${ }^{1}$ Department of Seed Science and Technology, ${ }^{2}$ Department of Genetics and Plant Breeding, \\ CCS Haryana Agricultural University, Hisar- 125 004, Haryana, India \\ *Corresponding author
}

\section{A B S T R A C T}

A study was conducted at Chaudhary Charan Singh Haryana Agricultural University,

\section{Keywords}

Wheat, Seed vigour, Field emergence, Seedling establishment, Regression analysis.

Article Info

Accepted:

07 September 2017

Available Online:

10 November 2017
Hisar for determining the ability of various seed vigour parameters to predict the field emergence of 34 varieties of wheat. Twelve seed vigour parameters were evaluated viz. test weight, standard germination, seedling length, seedling dry weight, vigour index-I, vigour index-II, accelerated ageing test, electrical conductivity, tetrazolium test, dehydrogenase activity test, field emergence index and seedling establishment. The regression analysis was done with respect to standard germination and seedling establishment. Results revealed that the estimated mean of seedling establishment obtained by various viability and vigour parameters viz. standard germination, vigour index-II, accelerated ageing, dehydrogenase activity test, tetrazolium test and vigour index-I were at par with the mean value obtained by observed seedling establishment in the field. The maximum value of $\mathrm{R}^{2}$ was obtained for standard germination, indicating the reliability of this test, followed by tetrazolium test, accelerated ageing test, dehydrogenase activity test, vigour index-I and vigour index-II. The study indicated the reliability of these tests to predict the field emergence in wheat.

\section{Introduction}

Seed is considered as the prime most important effective input of agriculture. The beliefs of agricultural experts say that 'a high quality seed is the introduction of a good agriculture' and in case of having non appropriate seed we won't have a good yield even with using the best other inputs.

Strong vigour, steady germination and good and fast seedling establishment in the field under a wide range of environmental conditions are important aspects of a good seed. Wheat (Triticum spp.) is one of the most important cereal crops of the world. It is common source of carbohydrates and proteins and is the staple food for about one third population of the world. Wheat is a widely adapted crop. It is grown in temperate, irrigated to dry and low rainfall areas to warm, humid and high rainfall areas. The option for increasing wheat production by expanding area under cultivation has already been exploited to almost its maximum. In modern agriculture, precision sowing is being introduced, seeding rates are being reduced, and more attention is being given to achieving maximum possible yields. These practices have enhanced the need to identify and sow 
high-vigour seed, particularly in adverse soil conditions (Latifi et al., 2004). Various laboratory tests have been presented by seed experts to identify seed quality and its performance in field. These tests are useful but there has been always a main problem: low relationship between these tests and real performance of seed in field. Therefore, studying the relationship between various laboratory tests and field performance of the seed becomes one of the most important research areas in seed technology science (Gastel and Pagnotta, 1996).

\section{Materials and Methods}

The seed material comprised of 34 varieties/genotypes, was obtained from Wheat and Barley Section, Department of Genetics and Plant Breeding, C.C.S. Haryana Agricultural University, Hisar in June 2014.The seeds of all the 34 varieties/genotypes (Table 1) were evaluated for twelve seed vigour parameters viz. test weight, standard germination, seedling length, seedling dry weight, vigour index-I, vigour index-II, accelerated ageing test, electrical conductivity, tetrazolium test, dehydrogenase activity test, field emergence index and seedling establishment.

1000 seeds were taken out for each variety/genotype and weighed for test weight. Standard germination test was conducted using between paper (BP) method at $20^{\circ} \mathrm{C}$.Seedling length (root + shoot) was measured on ten randomly selected normal seedlings taken from standard germination test samples and recorded in centimetres. These ten seedlings were dried in hot air oven for 24 hours at $80 \pm 1^{\circ} \mathrm{C}$. Average seedling dry weight of each genotype was calculated and expressed in milligrams. The seedling vigour indices were calculated by the method given by Abdul-Baki and Anderson (1973):
Vigour Index-I = Standard germination $(\%) \times$ Average seedling length $(\mathrm{cm})$

Vigour Index-II $=$ Standard germination $(\%)$ $\times$ Average seedling dry weight $(\mathrm{mg})$

For Accelerated ageing test, seeds of each variety/genotype were placed in a single layer on the wire mesh trays fitted in plastic boxes containing $40 \mathrm{ml}$ distilled water. The boxes were placed in ageing chamber at $40 \pm 1{ }^{\circ} \mathrm{C}$ and $100 \%$ relative humidity for 72 hours and tested for germination percentage. Electrical conductivity of the seed leachates was measured by observing the conductivity of the water in which 50 normal and undamaged seeds were immersed for 24 hours. Tetrazolium viability test was conducted according to Moore (1973) and viable seeds were expressed in percentage. Dehydrogenase activity (DHA) test was performed as per the standard procedure given by Kittock and Law (1968). Field emergence was recorded by sowing one hundred seeds of all genotypes in three replications in a Randomized Block Design (RBD) in the experimental field of Department of Seed Science \& Technology in November, 2014.The field emergence was determined by counting the total number of seedlings when the emergence was completed or when there was no further addition in total emergence.

\section{Statistical analysis}

The regression analysis was done with respect to standard germination and seedling establishment using the statistical program OPSTAT (Sheoranet al., 1998).The regression equations between different parameters were estimated as per the formula given below:

$\mathrm{Y}=\mathrm{a}+\mathrm{bX}$

Where, 
$\mathrm{Y}=$ dependent variable

$\mathrm{X}=$ independent variable

$\mathrm{a}=$ constant

$\mathrm{b}=$ regression coefficient

\section{Results and Discussion}

\section{Relationship between standard germination $(\%)$ and other viability and vigour parameters}

The simultaneous variation of the parameters which showed close relationship with standard germination was studied by regression analysis. The estimated mean germination percentage obtained by various parameters viz. tetrazolium (88.48\%), electrical conductivity (88.78\%), dehydrogenase activity (88.25\%) and accelerated ageing $(88.22 \%)$ were at par with the actual mean value of standard germination $(88.25 \%)$.

The actual mean with relation to estimated mean for all the parameters indicated in table 2 . The maximum value of $\mathrm{R}^{2}$ (coefficient of determination) was obtained for tetrazolium test $\left(\mathrm{R}^{2}=0.75\right)$ followed by accelerated ageing $\left(\mathrm{R}^{2}=0.61\right)$, dehydrogenase activity $\left(\mathrm{R}^{2}=0.59\right)$ and electrical conductivity $\left(\mathrm{R}^{2}=\right.$ 0.31 ) as these tests were found highly correlated with standard germination.

This study revealed the usefulness of tetrazolium test in the prediction of germination potential of wheat seed.

Table.1 List of varieties/genotypes used in the study

\begin{tabular}{|c|c|c|c|}
\hline Sr. No. & Name of Variety/Genotype & Sr. No. & Name of Variety/Genotype \\
\hline & Triticum aestivum (Bread wheat) & & \\
\hline 1. & C 518 & 19. & UP 2425 \\
\hline 2. & C 306 & 20. & KRL 19 \\
\hline 3. & KHARCHIA 65 & 21. & DB 1 14 \\
\hline 4. & SONALIKA & 22. & DBW 16 \\
\hline 5. & WH 147 & 23. & DBW 17 \\
\hline 6. & HUW 234 & 24. & WH 1025 \\
\hline 7. & HD 2285 (GOBIND) & 25. & HD 2967 \\
\hline 8. & KUNDAN (DL153-2) & 26. & WH 1105 \\
\hline 9. & WH 283 & 27. & WH 1124 \\
\hline 10. & PBW 175 & 28. & WH 1129 \\
\hline 11. & WH 157 & 29. & WH 1138 \\
\hline 12. & WH 542 & 30. & WH 896 \\
\hline 13. & KANCHAN (DL 803-3) & 31. & WH 912 \\
\hline 14. & RAJ 3765 & 32. & WHD 943 \\
\hline 15. & PBW 373 & 33. & 348 \\
\hline 16. & HD 2733 (VSM) & 34. & \\
\hline 17. & NW 1014 & \\
\hline 18. & SONAK &
\end{tabular}


Table.2 Relationship between Standard Germination (\%) and various viability and vigour tests for seed quality assessment in 34 wheat varieties/genotypes

\begin{tabular}{|c|c|c|c|c|c|}
\hline \multirow[b]{2}{*}{ Name of test } & \multicolumn{2}{|c|}{ Mean and Range } & \multirow[b]{2}{*}{$\begin{array}{l}\text { Correlation } \\
\text { (r) }\end{array}$} & \multirow{2}{*}{$\begin{array}{c}\text { Regression } \\
\mathbf{a}+(\mathbf{b}) \mathbf{x}\end{array}$} & \multirow[b]{2}{*}{$\begin{array}{c}\text { R- } \\
\text { Square }\end{array}$} \\
\hline & $\begin{array}{l}\text { Actual mean of } \\
\text { independent } \\
\text { parameter(x) }\end{array}$ & $\begin{array}{c}\text { Estimated mean } \\
\text { of dependent } \\
\text { parameter }\end{array}$ & & & \\
\hline Tetrazolium (\%) & $\begin{array}{c}93.54 \\
(79.67-99.33)\end{array}$ & 88.48 & $0.87 * *$ & $-22.61+(1.24) \mathrm{x}$ & 0.75 \\
\hline $\begin{array}{l}\text { Accelerated ageing } \\
\text { [72hrs] }(\%)\end{array}$ & $\begin{array}{c}45.12 \\
(35.67-54.67) \\
\end{array}$ & 88.22 & $0.78 * *$ & $34.98+(1.18) x$ & 0.61 \\
\hline $\begin{array}{l}\text { Dehydrogenase } \\
\text { Activity (O.D.) }\end{array}$ & $\begin{array}{c}0.288 \\
(0.111-0.465) \\
\end{array}$ & 88.25 & $0.77 * *$ & $71.84+(56.99) \mathrm{x}$ & 0.59 \\
\hline $\begin{array}{l}\text { Electrical conductivity } \\
(\mu \mathrm{S} / \mathrm{cm} / \mathrm{seed})\end{array}$ & $\begin{array}{c}140.05 \\
(88.67-202.67)\end{array}$ & 88.78 & $-0.56 * *$ & $106.99+(-0.13) x$ & 0.31 \\
\hline
\end{tabular}

$* *$ Significant at $1 \%$

Standard Germination is dependent parameter. Actual mean $=88.25 \%$

Table.3 Relationship between seedling establishment (\%) and various viability and vigour tests for seed quality assessment in 34 wheat varieties/genotypes

\begin{tabular}{|c|c|c|c|c|c|}
\hline \multirow[b]{2}{*}{ Name of test } & \multicolumn{2}{|c|}{ Mean and Range } & \multirow[b]{2}{*}{ Correlation(r) } & \multirow{2}{*}{$\begin{array}{c}\text { Regression } \\
a+(b) x\end{array}$} & \multirow[b]{2}{*}{$\begin{array}{c}\text { R- } \\
\text { Square }\end{array}$} \\
\hline & $\begin{array}{c}\text { Actual mean of } \\
\text { independent } \\
\text { parameter(x) }\end{array}$ & $\begin{array}{c}\text { Estimated mean } \\
\text { of dependent } \\
\text { parameter }\end{array}$ & & & \\
\hline Standard Germination (\%) & $\begin{array}{c}88.56 \\
(72.33-98.67)\end{array}$ & 75.65 & $0.84 * *$ & $-10.694+(0.98) x$ & 0.71 \\
\hline Tetrazolium (\%) & $\begin{array}{c}93.54 \\
(79.67-99.33)\end{array}$ & E75.60 & $0.79 * *$ & $-45.351+(1.29) \mathrm{x}$ & 0.63 \\
\hline $\begin{array}{l}\text { Accelerated ageing [72hrs] } \\
(\%)\end{array}$ & $\begin{array}{c}45.36 \\
(35.67-54.67) \\
\end{array}$ & 75.62 & $0.64 * *$ & $21.643+(1.19) x$ & 0.41 \\
\hline $\begin{array}{l}\text { Dehydrogenase Activity } \\
\text { (O.D.) }\end{array}$ & $\begin{array}{c}0.293 \\
(0.111-0.461)\end{array}$ & 75.62 & $0.61 * *$ & $59.038+(56.59) x$ & 0.37 \\
\hline VI-I $[\mathrm{SG}(\%) \times \mathrm{SL}(\mathrm{cm})]$ & $\begin{array}{c}2026.26 \\
(1391.7-3022.1) \\
\end{array}$ & 75.06 & $0.56 * *$ & $52.775+(0.01) x$ & 0.31 \\
\hline VI-II [SG(\%)×SDW(g)] & $\begin{array}{c}12.90 \\
(8.73-18.30) \\
\end{array}$ & 75.64 & $0.55^{* *}$ & $54.010+(1.68) x$ & 0.30 \\
\hline
\end{tabular}

**Significant at $1 \%$

Seedling establishment is dependent parameter. Actual mean $=75.64 \%$

Relationship between seedling establishment (\%) and various viability and vigour parameters

The estimated mean of seedling establishment obtained by different viability and vigour parameters viz. standard germination (75.65\%), vigour index II (75.64\%), accelerated ageing (75.62\%), dehydrogenase activity $(75.62 \%)$, tetrazolium $(75.60 \%)$ and vigour index I $(75.06 \%)$ were found at par with observed mean value of seedling establishment in the field $(75.64 \%)$ as shown in table 3 .

The maximum value of $\mathrm{R}^{2}(0.71)$ was obtained for standard germination, indicating the reliability of the test, followed by tetrazolium $\left(\mathrm{R}^{2}=0.63\right)$, accelerated ageing $\left(R^{2}=0.41\right)$, dehydrogenase activity $\left(R^{2}=\right.$ 
$0.37)$, vigour index $I\left(R^{2}=0.31\right)$ and vigour index-II $\left(R^{2}=0.30\right)$. The concurrent variation of all these parameters which showed close relationship with standard germination and seedling establishment was studied by regression analysis. In this study, the most accurate prediction of seedling establishment was obtained from standard germination, indicating the reliability of this test, followed by tetrazolium test, accelerated ageing, dehydrogenase activity, vigour index-I and vigour index-II. In some previous studies based on regression analysis, standard germination test was concluded to be the best predictor of field performance in alfalfa (Tavacoli et al., 2005) and chickpea (Qasim et al., 2010). Some regression models suggested by Naderidarbaghshahi (2013) also showed better efficiency of standard germination in prediction of field emergence in bean, cotton, barley, sunflower and found accelerated ageing test better for colza. From the present study, it can be concluded that Standard Germination, Accelerated Ageing and Tetrazolium Test for wheat crop have the potential to be used as reliable vigour tests for ranking seed lot quality and predicting field emergence.

\section{References}

Abdul-Baki, A.A., and Anderson, J.D. 1973.Physiological and Biochemical Deterioration of Seed Biology, T. T. Koziowski (Ed.). Academic Press, New York. pp. 283-315.

Gastel, A.J.V., and Pagnotta, M.A. 1996. Seed Science and Technology. ICARDA, Aleppo, Syria.
Kittock, D.L. and Law, A.G. 1968. Relationship of seedling vigour to respiration and tetrazolium chloride reduction by germinating wheat seeds. Agronomy Journal. 60: 286-288.

Latifi, N., Soltani, A. and Spanner, D. 2004. Effect of temperature on germination components in Canola (Brassica napus L.) cultivars. Iranian J. Agri. Sci. 35(2): 313-321.

Moore, R.P. 1973. Tetrazolium stain for assessing seed quality. Seed Ecology. pp: 347-366.

Naderidarbaghshahi, M. 2013. Do correlation coefficient and regression models able to describe relationship between laboratory seed vigour tests and field seed emergence of crops. Journal of Novel Applied Sciences. 2(12): 678682.

Qasim, G., Malik, A.U., Sarfraz, M., Bukhsh, M.A.A.H.A., and Ishaque, M. 2010.Relationship between laboratory seed quality tests, field emergence and yield of chickpea. Crop and Environment.1: 31-34.

Sheoran, O.P., Tonk, D.S., Kaushik, L.S., Hasija, R.C., and Pannu, R.S. 1998. Statistical Software Package for Agricultural Research Workers. In: Recent Advances in information theory, Statistics \& Computer Applications by D.S. Hooda \& R.C. Hasija Department of Mathematics Statistics, CCS HAU, Hisar., pp. 139-143.

Tavacoli, H., Behesti, A., and Nasirimhalati, M. 2005. Assessment of seed alfalfa quality by seed tests. Journal of Agronomic Research. 3(1): 25-32.

\section{How to cite this article:}

Sushma Sharma, R.C. Punia, Vikram Singh, V.S. Mor and Hemender. 2017. Prediction of Seedling Establishment in Field by Using Various Seed Vigour Parameters in Wheat (Triticum spp.). Int.J.Curr.Microbiol.App.Sci. 6(11): 410-414. doi: https://doi.org/10.20546/ijcmas.2017.611.047 